\title{
Effect of divalent chloride salts on lamellar silica conductivity
}

\section{(Efeito de sais de cloretos divalentes na condutividade da sílica lamelar)}

\author{
A. C. P. C. de Araujo, M. G. Cavalcante \\ Instituto de Química, Universidade Federal do Rio Grande do Norte, C.P. 1662, Natal, RN, Brazil 59072-970 \\ carolpaivac@yahoo.com.br,m.gorette@zipmail.com.br
}

\begin{abstract}
Silica is an important raw material in the production of soluble silicates, silicon and its derivatives: silicon carbide and silicone, which are converted into the lamellar form using the sol-gel process. This compound, which has been extensively studied because it is structurally organized, can be used for selective adsorption of toxic substances or immobilization of photo-active species. Impedance spectroscopy was used in a study of the electrical properties of lamellar silica doped with the following metal salts: nickel chloride, manganese chloride, and copper chloride, in order to observe the cation effect in their structure. In this study, the following order of conductivity was obtained: manganese chloride> nickel chloride $>$ copper chloride. This effect was also observed using X-ray diffraction analysis.
\end{abstract}

Keywords: lamellar silica, ionic adsorption, conductivity.

\section{Resumo}

A sílica é uma importante matéria prima para a produção de silicatos solúveis, silício e seus derivados: carboneto de silício e silicone, os quais são convertidos na forma lamelar através do processo sol-gel. Este composto, que tem sido extensivamente estudado, por ser estruturalmente organizado pode ser usado para a adsorção selectiva de substâncias tóxicas ou imobilização de espécies foto-ativas. Espectroscopia de impedância foi utilizada em um estudo sobre as propriedades eléctricas de sílica lamelar dopadas com os seguintes sais metálicos: cloreto de níquel, cloreto de manganês e cloreto de cobre, a fim de observar o efeito dos cátions na sua estrutura. Neste estudo, a seguinte ordem de condutividade foi obtido: cloreto de manganês > cloreto de níquel > cloreto de cobre. Este efeito também foi observado usando análise de difração de raios $X$.

Palavras-chave: sílica lamelar, adsorção iônica, condutividade.

\section{INTRODUCTION}

The term silica refers to the silicon dioxide compounds $\left(\mathrm{SiO}_{2}\right)$ in their various forms, including crystalline silica and amorphous silica. Silicon dioxide is formed by the two most abundant elements, oxygen and silicon, composing for around $60 \%$ of the mass of the earth's crust. The silica deposits originated in different geological eras. Most of these deposits, which are mineralized to obtain "silica sand", consist of free quartz, quartzite and sedimentary deposits such as sandstones [1-7]. Commercially, silica is a source of the element silicon and is used in large amounts in construction materials. Silica also has numerous specialized applications, such as piezoelectric crystals [1, 4-5]. In its amorphous form, silica is used as a desiccant, adsorbent and catalyzing component. In its vitreous form it is widely used in the glass industry and as optical components $[1,8]$. Pure, doped or functionalized silica can be synthesized by the sol-gel process. It can also be prepared from supersaturated solutions of siliceous acid. Silica gel, modified by an organofunctionalizing agent, can be used as a support for catalyzers, chromatography or as a chelating agent for metal complexation in solution [5-9, 10-13].

The sol-gel process is quite attractive when compared to syntheses involving siliceous acids, because it is conducted at low temperatures (close to ambient temperature) and owing to the rapidity in which the product is obtained, ranging from a few minutes to a few hours [1, 10-11].

Farias et al $[8,11]$ have reported that the presence de diamine molecules in inorganic-organic lamellar silica can act as a suitable agent with a strong ability in coordinating transition metal cations, due to the diamine is located in the interlayer space of the lamellar silica. Inorganic-organic hybrids such as lamellar silica can be successfully synthesized through sol-gel process, by using the so-called neutral amine route $[12,13]$.

The discharge of domestic and industrial waste, as well as metal toxicity in aquatic organisms, is a worrisome problem for society, which is seeking solutions to remove these metals from the environment. Nickel, for example, is used in industrial applications such secondary battery production $[14$, 15]. Human contact with this metal may lead to skin diseases [14]. Copper that is used in various fields such as catalysis, electronics and photoelectronics, among others [16], can also pollute the environment and cause serious problems such as stomach intestinal distress, kidney damage and anemia [17]. Manganese, one of the main components of alkaline batteries, may pollute the groundwater, causing great environmental impact through the improper disposal of these batteries [18]. 
Therefore, effective, low-cost and easy-to-apply methods are needed to remove these materials from the environment, and one of these is adsorption on the surface of certain materials [1, 4]. Güzel et al [17] studied the degree of sulfate adsorption of manganese, nickel and copper, using the Langmuir isotherm and observing the following order of adsorption: $\mathrm{Cu}>\mathrm{Ni}>\mathrm{Mn}$.

The aim of the present investigation were to study the influence on the electrical properties of lamellar silica caused by changes in its structure with the addition of dopants (transition metals in the form of chlorides: $\mathrm{MnCl}_{2}, \mathrm{NiCl}_{2}$ and $\mathrm{CuCl}_{2}$ ). Using impedance spectroscopy, conductivities of the lamellar silica-chloride system were obtained from the electrical parameters extracted from the analysis of Nyquist diagrams. X-ray diffractograms were also obtained since it is a convenient and practical method for the qualitative identification of crystalline compounds.

\section{EXPERIMENTAL}

\section{Preparation of doped lamellar silica [6]}

Lamellar silica was obtained by the addition of $1.00 \mathrm{x}$ $10^{-2} \mathrm{~mol}$ of 1,12-diaminododecane (DADD) for a mixture of $0.50 \mathrm{~mol}$ of n-propanol and $3.30 \mathrm{~mol}$ of distilled water. This mixture was kept under magnetic agitation for $10 \mathrm{~min}$, forming a homogeneous phase. Afterwards $1.00 \times 10^{-2} \mathrm{~mol}$ of tetraethylorthosilicate (TEOS) was added. Through a syringe and, after $3 \mathrm{~min}$, the gel was formed. This resulting product was aged for $24 \mathrm{~h}$ at room temperature.

The sample of lamellar silica obtained was doped with the metal through the addition of $10 \mathrm{mmol}$ of $\mathrm{MnCl}_{2}, \mathrm{NiCl}_{2}$, and $\mathrm{CuCl}_{2}$, to the gel previously aged for $24 \mathrm{~h}$. The obtained hybrids were dried under vacuum at $353 \mathrm{~K}$ for $8 \mathrm{~h}$.

\section{Impedance spectroscopy}

Electrical conductivity of the material analyzed was obtained using impedance spectroscopy and a frequency response analyzer (Autolab), along with an electrochemical interface (Eco Chemie Autolab USB). The powder samples of lamellar silica doped with the different salts were analyzed by placing them between stainless steel cylindrical electrodes. Electrochemical measurements were taken over a frequency range $1.0 \mathrm{mHz}$ to $1.0 \mathrm{MHz}$, with an amplitude of $0.1 \mathrm{~V}$.

\section{$X$-ray diffraction}

X-ray diffractograms were obtained using a Shimadzu XRD-6000 X-ray diffractometer, with a scan range between $2^{\circ}$ and $80^{\circ}$, scan step 0.02 , and $2^{\circ} / \mathrm{min}$.

\section{RESULTS AND DISCUSSION}

\section{X-ray diffraction analysis}

The X-ray diffractograms of lamellar silica doped with $\mathrm{CuCl}_{2}, \mathrm{MnCl}_{2}$, and $\mathrm{NiCl}_{2}$ are shown in Fig. 1 .

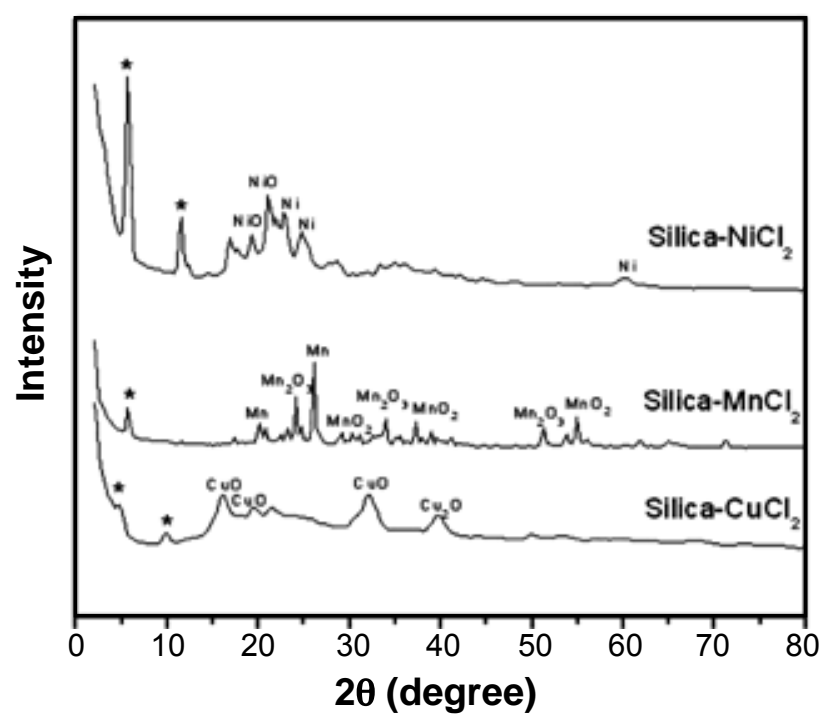

Figure 1: X-ray diffraction patterns of lamellar silica doped with $\mathrm{MnCl}_{2}, \mathrm{NiCl}_{2}$, and $\mathrm{CuCl}_{2}$. (*) Peaks of pure lamellar silica. [Figura 1: Difratogramas de raios $X$ da sílica lamelar dopada com $\mathrm{MnCl}_{2}, \mathrm{NiCl}_{2}$, and $\mathrm{CuCl}_{2}$. (*) Picos da silica lamelar pura.]

According to Farias et al [11], the X-ray diffractograms of pure lamellar silica show peaks at $3.8^{\circ}, 7.3^{\circ}$ and $11.5^{\circ}$. However, for chloride-doped lamellar silica, this study found that these peaks were slightly displaced from these angular positions. These obtained results are an indication that when metal salts are added to the lamellar silica, the normal diamine chains change the intra-lamellar re-arrangement, to allow the basic nitrogen centers to coordinate the cation. For the $\mathrm{CuCl}_{2}-$ doped lamellar silica these peaks are located at $5.0^{\circ}$ and $10.0^{\circ}$, respectively, with peaks for $\mathrm{CuO}$ also appearing at $16.2^{\circ}$, $19.7^{\circ}$ and $32^{\circ}$ and another for $\mathrm{Cu}_{2} \mathrm{O}$ at $39.7^{\circ}$ [15, 18-19]. The diffractogram of lamellar silica doped with manganese salt shows only one lamellar silica peak at $6.0^{\circ}$, indicating that this salt masks the peak at $11.5^{\circ}$. Other peaks, corresponding to $\mathrm{Mn}, \mathrm{Mn}_{2} \mathrm{O}_{3}, \mathrm{Mn}, \mathrm{MnO}_{2}, \mathrm{Mn}_{2} \mathrm{O}_{3}, \mathrm{MnO}_{2}, \mathrm{Mn}_{2} \mathrm{O}$ and $\mathrm{MnO}_{2}$, appear at $20.3^{\circ}, 24.1^{\circ}, 26.1^{\circ}, 30.6^{\circ}, 34^{\circ}, 37.3^{\circ}, 51.4^{\circ}$ and $56^{\circ}$, respectively [20-25]. The diffractogram for $\mathrm{NiCl}_{2}$-doped lamellar silica shows peaks corresponding to pure lamellar silica at $6.0^{\circ}$ and $11.6^{\circ}$, peaks at $19.4^{\circ}$ and $21.8^{\circ}$, corresponding to $\mathrm{NiO}$, and others at $22.9^{\circ}, 2.7^{\circ}$ and $60.2^{\circ}$ for nickel $[9,26]$. The X-ray diffraction patterns show then a decrease in the inter-lamellar space of the pure lamellar silica occurred with the addition of the metal salts as follows: $\mathrm{CuCl}_{2}>\mathrm{NiCl}_{2}>$ $\mathrm{MnCl}_{2}$.

\section{Analysis of Nyquist diagrams}

Fig. 2 shows Nyquist diagrams, with a single semicircle, for lamellar silica doped with $\mathrm{CuCl}_{2}, \mathrm{MnCl}_{2}$, and $\mathrm{NiCl}_{2}$. Semicircles can be observed in the low frequency region for lamellar silica doped with $\mathrm{CuCl}_{2}\left(v_{\max }=3.98 \mathrm{~s}^{-1}\right)$ and $\mathrm{NiCl}_{2}\left(v_{\text {max }}=3.12 \mathrm{~s}^{-1}\right)$, while the semicircle corresponding to lamellar silica doped with $\mathrm{MnCl}_{2}$ is only found in the higher frequency region $\left(v_{\max }=45.60 \mathrm{~s}^{-1}\right)$. 


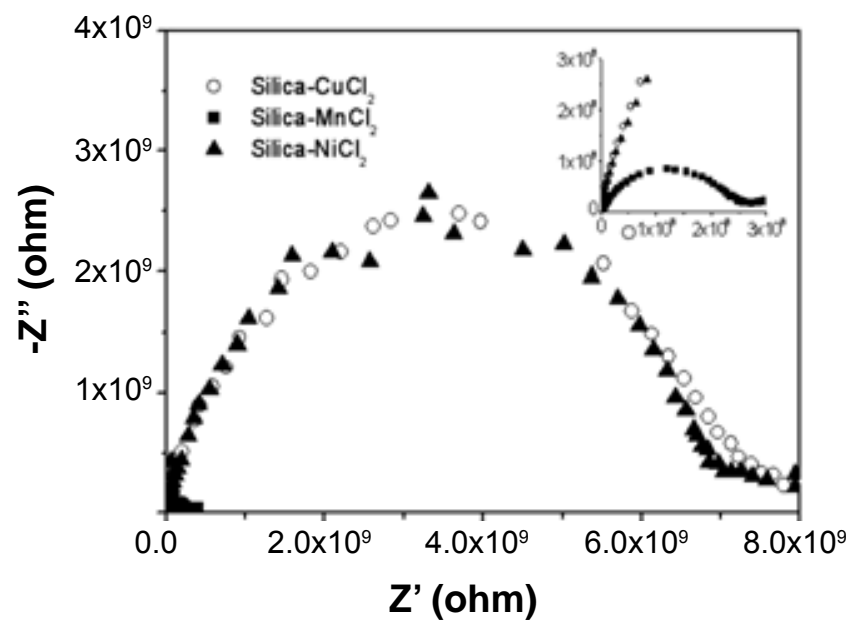

Figure 2: Nyquist diagrams of lamellar silica doped with $\mathrm{MnCl}_{2}$, $\mathrm{NiCl}_{2}$, and $\mathrm{CuCl}_{2}$.

[Figura 2: Diagramas de Nyquist da sílica lamelar dopada com $\mathrm{MnCl}_{2}, \mathrm{NiCl}_{2}$, and $\left.\mathrm{CuCl}_{2} \cdot\right]$

Thus, always considering a same counter-ion for the cation studied, the matrix obtained by the reaction between the silicon modified with DADD and chloride exhibits the following adsorption capacity in the presence of the divalent ions: $\mathrm{Cu}^{2+}>\mathrm{Ni}^{2+}>\mathrm{Mn}^{2+}$. This adsorption capacity decreases as a consequence of the metal:ligand ratio for the complexes formed [1]. It may also be influenced by the cation ionic radius (Ionic radius: $\mathrm{Cu}^{2+}=72 \mathrm{pm} ; \mathrm{Ni}^{2+}=78$ $\mathrm{pm} ; \mathrm{Mn}^{2+}=91 \mathrm{pm}$ ), since the smaller its ionic radius, the greater its capacity to be adsorbed. This behavior seems to be confirmed by the shift of the semicircles shown in Fig. 2 in relation to the frequency regions studied. The semicircle corresponding to the $\mathrm{Mn}^{2+}$ ion appears in a region of higher frequency, likely because this ion has the higher ionic radius of all the ions used, then it can is more free for if to move on the crystalline lattice of the lamellar silica, being therefore the least adsorbed. This observed effect is in agreement with the X-ray diffraction patterns that suggest a higher interlamellar space for the $\mathrm{MnCl}_{2}$ - doped lamellar silica.

\section{Electrical properties of silica with chloride salts}

The parameters obtained from impedance spectroscopy are summarized in Table I. According to these data, ohmic resistance (or resistance of the material) $\mathrm{R}_{\Omega}$, increases as follows: $\mathrm{CuCl}_{2}>\mathrm{NiCl}_{2}>\mathrm{MnCl}_{2}$, which is compatible with the adsorption capacity of the cation on the lamellar silica surface, that is, since $\mathrm{CuCl}_{2}$ is the most adsorbed by the silica, structural packing becomes more compact, difficult the conduction process of the salt. This cation adsorption behavior was also observed by Güzel et al [16] using Langmuir isotherms.

The lamellar silica- $\mathrm{MnCl}_{2}$ system shows higher conductivity, $\left.\sigma=1.52 \times 10^{-4} \Omega^{-1} . \mathrm{cm}^{-1}\right)$, but the same order of magnitude as the silica- $\mathrm{NiCl}_{2}\left(1.31 \times 10^{-4} \Omega^{-1} \cdot \mathrm{cm}^{-1}\right)$. However, the lamellar silica doped with $\mathrm{CuCl}_{2}$ had the lowest conductivity $\left(8.17 \times 10^{-5} \Omega^{-1} \cdot \mathrm{cm}^{-1}\right)$ among the systems
Table I - Electrical properties of lamellar silica doped with metallic salts.

[Tabela I - Propriedades elétricas da sílica lamelar dopada com sais metálicos.]

\begin{tabular}{cccc}
\hline Salts & $\mathrm{R}_{\Omega} /\left(10^{+3} \Omega\right)$ & $v_{\text {maxx }} / \mathrm{s}^{-1}$ & $\sigma /\left(\Omega^{-1} \cdot \mathrm{cm}^{-1}\right)$ \\
\hline $\mathrm{MnCl}_{2}$ & 5,26 & 45,60 & $1,52 \times 10^{-4}$ \\
$\mathrm{NiCl}_{2}$ & 6,10 & 3,12 & $1,31 \times 10^{-4}$ \\
$\mathrm{CuCl}_{2}$ & 9,80 & 3,98 & $8,17 \times 10^{-5}$ \\
\hline
\end{tabular}

studied (Table I). This behavior is likely due not only to the size of the ionic radius, but also to the $3 \mathrm{~d}$ orbital, which for both $\mathrm{Ni}\left([\operatorname{Ar}] 3 \mathrm{~d}^{8} 4 \mathrm{~s}^{2}\right)$ and $\operatorname{Mn}\left([\operatorname{Ar}] 3 \mathrm{~d}^{5} 4 \mathrm{~s}^{2}\right)$ is partially occupied, whereas in $\mathrm{Cu}\left([\mathrm{Ar}] 3 \mathrm{~d}^{10} 4 \mathrm{~s}^{1}\right)$ this orbital is totally occupied.

As shown in the Nyquist diagrams, the dependence of the semicircles in relation to frequency is directly linked to the type of dopant in the silica. The fact that the diffractograms of lamellar silica doped with $\mathrm{CuCl}_{2}$ show more silica peaks and few dopant related peaks indicates agreement with impedance, in which it is found to be the most adsorbed dopant in the lamellar silica. On the other hand, lamellar silica doped with $\mathrm{MnCl}_{2}$ shows only one peak corresponding to pure lamellar silica and several dopant related peaks, demonstrating that this dopant is less adsorbed on the silica surface, and therefore, exhibits greater conductivity.

\section{CONCLUSIONS}

Impedance spectroscopy shows that lamellar silica doped with chloride salts shows the following conductivity order: $\mathrm{MnCl}_{2}>\mathrm{NiCl}_{2}>\mathrm{CuCl}_{2}$, likely owing to the degree of adsorption of the cation in the silica. Since $\mathrm{Mn}^{2+}$ is less adsorbed, it is free to move around the silica surface. The X-ray diffractograms are also in agreement with the impedance results, given that one can observe more peaks related to pure silica doped with $\mathrm{CuCl}_{2}$, while silica doped with $\mathrm{MnCl}_{2}$ displays more peaks related to $\mathrm{Mn}^{2+}$ and its oxides, demonstrating that it is the least adsorbed metal. Therefore, metallic salt dopants have a significant effect on the electrical properties of lamellar silica, due to the adsorption capacity of each cation in the lamellar silica.

\section{ACKNOWLEDGEMENTS}

Ana Carolina P. C. de Araujo thanks CNPq for the fellowship. The authors thank FINEP for the financial support, and R. F. de Farias from Universidade Federal do Rio Grande do Norte, who kindly provided the samples.

\section{REFERENCES}

[1] R. F. de Farias (Ed.), "Química de Coordenação: Fundamentos e Atualidade", Ed. Átomo, Campinas, SP (2005) p. 138.

[2] D. L. Santana, A. C. F. Saraiva, R. F. Neves, D. L. Silva, 
Cerâmica 58, 346 (2012) 238-243.

[3] J. F. Cardenas, Colloids Surfaces A: Physicochem. Eng. Aspects 252 (2005) 213.

[4] L. C. Bandeira, P. S. Calefi, K. J. Ciuffi, E. J. Nassar, I. M. M. Salvado, M. H. F. V. Fernandes, Cerâmica 57 (2011) 166-172.

[5] H. S. Zhou, D. Kundu, I. Honma, J. Eur. Ceram. Soc. 19 (1999) 1361.

[6] R. F. de Farias, C. Airoldi, Química Nova 23 (2000) 88.

[7] A. G. S. Prado, E. A. Faria, Química Nova 28, 3 (2005) 544-547

[8] R. F. de Farias, C. Airoldi, Colloids Surfaces A: Physicochem. Eng. Aspects 172 (2000) 145.

[9] G. G. Lenzi, M. K. Lenzi, M. L. Baesso, A. C. Bento, O. A. A. Santos, J. Non-Crystalline Solids 354 (2008) 4811. [10] H. Mao, B. Li, X. Li, Z. Liu, W. Ma, Mater. Res. Bull. 44 (2009) 1569.

[11] R. Farias, C. Airoldi, J. Non-Crystalline Solids 261 (2000) 181.

[12] N. F. Sales, V. C. Costa, W. L. Vasconcelos, Mater. Sci. Eng. A, 408 (2005) 121.

[13] W. Cho, R. Saxena, O. Rodriguez, R. Achanta, J. L. Plawsky, W. N. Gill, J. Non-Crystalline Solids 350 (2004) 336.

[14] R. C. Ambrosio, E. A. Ticianelli, Química Nova 24 (2001) 243.
[15] I. L. Küchler, F. A. M. Silva, Química Nova 22 (1999) 339.

[16] Y. Kobayashi, T. Sakuraba, Colloids Surfaces A: Physicochem. Eng. Aspects 317 (2008) 756.

[17] F. Güzel , H. Yakut, G. Topal, J. Hazardous Mater. 153 (2008) 1275.

[18] D. C. Rascio, R. F. B. Souza, E. T. Neto, H. B. Suffredini, M. C. Santos, M. L. Calegaro, Química Nova 33 (2010) 730.

[19] A. Corrias, G. Paschina, P. Sirigu, J. Non-Crystalline Solids 232 (1998) 358.

[20] B. Dong, L. Cao, G. Su, W. Liu, H. Qu, D. Jiang, J. Colloid Interface Sci. 339 (2009) 78.

[21] S.-F. Ji, T.-C. Xiao, S.-B. Li, C.-Z. Xu, R.-L. Hou, K. S. Colemanb, M. L. H. Green, Appl. Catalysis A: General 225 (2002) 271

[22] A. Tawansi, A. El-khodary, H. M. Zidan, S. I. Badr, Polymer Testing 21 (2002) 381.

[23] P. Hu, H.-B. Yang, D.-A. Pan, H. Wang, J.-J. Tian, S.-G. Zhang, X.-F. Wang, A. A.Volinsky, J. Magnetism Magnetic Mater. 322 (2010) 173.

[24] C. Ye, Z. M. Lin, J. X. Yan, Solid State Comm. 133 (2005) 121.

[25] J. Wang, L. Chou, B. Zhang, H. Song, J. Zhao, J. Yang, S. Li, J. Molecular Catalysis A: Chemical 245 (2006) 272.

[26] H. Mao, B. Li, X. Li, Z. Liu, W. Ma, Mater. Res. Bull. 44 (2009) 1569.

(Rec. 12/03/2013, Ac. 04/06/2013) 